microbiologists, physiologists and others having in common an interest in the cell. The organization has been named the American Society for Cell Biology. Applications to join the Society should be sent to Dr. Montrose J. Moses, Box 2982, Duke University School of Medicine, Durham, N.C. Membership is not restricted to residents of the United States.

\section{Maccabæan Prize and Medal}

Through the generosity of the Maccabrans, the Faculty of the History of Medicine and Pharmaey of the Worshipful Society of Apothecaries is able to offer an annual prize of not less than 25 guineas, with a bronze medal, for the best original essay on a subject connected with the history of medicine or pharmacy written by an undergraduate or graduate less than thirty years of age. Further information can be obtained from Dr. F. N. L. Poynter, The Wellcome Historical Medical Library, 183 Euston Road, London, N.W.I.

\section{Research in Biochemistry and Allied Sciences}

A Colloqurum on the Organization and Financing of Research in Biochemistry and Allied Sciences is to be held under the joint auspices of the Biochemical Society and the British Association, in the Physiology Institute, Newport Road, Cardiff, on September 7 (the last day of the British Association meeting) at 2 p.m. It is expected that the following speakers will take part : Prof. John Pryde (chairman), Prof. A. Haddow (British Empire Cancer Campaign), Dr. F. J. C. Herrald (Medical Research Council), Sir William Slater (Agricultural Research Council), Mr. C. Jollife (Department of Scientific and Industrial Research), Dr. G. F. Marrian (Imperial Cancer Research Fund), Prof. F. C. Happold (University of Leeds), Dr. F. A. Robinson (on behalf of industry), Dr. J. B. Bateman (U.S. Embassy, London), Prof. A. Neuberger (St. Mary's Hospital Medical School). The Colloquium is being organized jointly by Dr. K. S. Dodgson, Physiology Institute, University College, Newport Road, Cardiff, and Dr. W. J. Whelan (meeting secretary of the Biochemical Society), from whom particulars can be obtained.

\section{The Night Sky in September}

FULI moon occurs on Sept. 5d. 11h. 19m. U.T., and new moon on Sept. 20d. 23h. 13m. Th $ə$ following conjunctions with the Moon take place: Sept. Id. 08h., Saturn $4^{\circ}$ S.; Sept. 12d. 0lh., Aldebaran $0 \cdot 2^{\circ}$ S.; Sept. 13d. 10h., Mars $5^{\circ}$ N.; Sept 22 d. $22 \mathrm{~h}$., Venus $3^{\circ}$ S. ; Sept. 27 d. 10h., Jupiter $5^{\circ}$ S.; Sept. 28d. 14h., Saturn $4^{\circ} \mathrm{S}$. In addition to these conjunctions with the Moon, Vonus is in conjunction with Spica on Sopt. 20d. 22h., Venus being $3^{\circ} \mathrm{N}$.; and Mercury with Spica on Sept. 26d. 16h., Mercury being $1^{\circ} \mathrm{N}$. There will be a total eclipse of the Moon on September 5 and a partial eclipse of the Sun on September 20-21; both eclipses will be invisible at Grecnwich. There were two eclipses in March of this year, making in all four in 1960. As is usually the case when four eclipses occur in a year, they take place in pairs about six months apart. Mercury and Venus are too close to the Sun for observation. Mars rises at $22 \mathrm{~h} .15 \mathrm{~m} ., 21 \mathrm{~h} .50 \mathrm{~m}$. and $21 \mathrm{~h} .20 \mathrm{~m}$. at the beginning, middle and end of the month, respectively. It is in Taurus at the beginning of September and moves into Gemini on Sept. 20. Mars is rapidly becoming brighter, its stellar magnitude being +0.5 and its distance from the Earth 106 million miles in the middle of the month. Jupiter sets at $22 \mathrm{~h} .40 \mathrm{~m}$., $2 \mathrm{lh} .50 \mathrm{~m}$. and $20 \mathrm{~h} .55 \mathrm{~m}$. on September 1, 15 and 30 , respectively; it is in Ophiuchus, but conditions are not very favourable for observation. Its stellar magnitude is -1.8 and its distance from the Earth on September 15 is 470 million miles. Saturn is in Sagittarius, east of Jupiter, and sets at $0 \mathrm{~h} .00 \mathrm{~m} ., 23 \mathrm{~h}$. $05 \mathrm{~m}$. and $22 \mathrm{~h}$. $05 \mathrm{~m}$. at the beginning, middle and end of the month, respectively. It is stationary on September 15 and afterwards resumes eastward motion among the stars. Its stellar magnitude is +0.6 and its distance from the Earth in the middle of the month is 890 million miles. Occultations of stars brighter than magnitude 6 are as follows, observations being made at Greenwich: Sept. 9d. 4h. 45.1m., $\xi^{1}$ Cet. $(D)$; Sept. 12d. 1h. 14·3m., 89 Tau. $(R)$; Sept. 12d. lh. $21 \cdot 3 \mathrm{~m} ., \sigma^{2}$ Tau. $(R)$; Sept. 13d. Ih. 05.0m., 117 Tau. $(R) . \quad D$ and $R$ refer to disappearance and reappearance, respectively. The autumnal equinox occurs on Sept. 23d. 01h.

\section{Announcements}

Mr. M. D. TAYLOR, of the Department of Chemical Engineering, King's College, University of Durham, has been awarded a CJB Scholarship, of the value of $£ 450$ per annum, for two years in the first instance. This scholarship scheme, administered jointly by Constructors John Brown, Ltd., and the Institution of Chemical Engineers, is to encourage research in chemical engineering and, in particular, in chemical plant design.

AN International Symposium on Photoelasticity will be held during October 29-31, 1961, at the Illinois Institute of Technology, Chicago, Illinois. Further information can be obtained from $\mathrm{Dr}$. Paul D. Flynn, Illinois Institute of Technology, Chicago 16, Tllinois.

A symposium on Redox Processes will be held at the Chemical Laboratories, University of Allahabad, under the auspices of the Chemical Research Committee, Council of Scientific and Industrial Research, India, during January 1961. Further information can be obtained from Dr. Satya Prakash, Department of Chemistry, University of Allahabad.

A CONFERENCE on Diffraction will be held during November $9-11$ at the Mellon Institute, Pittsburgh, Pennsylvania. Sessions will be devoted to metals and alloys, instrumentation, structures, polymers and fibres, refractories, electron probes and electron diffraction. Further information can be obtained from L. F. Vassamillet, Mellon Institute, 4400 Fifth Avenue, Pittsburgh 13, Pennsylvania.

THE Institution of Electronics, with the cooperation of the Hull Electronic Engineering Society, is to hold an Electronics and Instruments Exhibition and Convention at the Farmery Hall, George St., Hull, during the period September 28-30. Admission will be free of charge and by tickets obtainable from exhibitors, or from W. Birtwistle, General Secretary, Institution of Electronics, 78 Shaw Road, Rochdale, Lanes., or from C. W. Wyan, Honorary Secretary, Hull Electronic Engineering Society, 2 Lockton Grove, Calvert Road, Hull, Yorks.

Erratum. In the communication entitled "Structure of $\beta$-Acylacrylic Acids", by Prof. Nils Hellström, in Nature of July $9, p .146$, the description of the ordinate of Fig. I is incorrect; for "Acid/sodium hydroxide" read "Sodium hydroxide/acid". 